\title{
HERMENUTIKA YUSUF AL-QORDAWI DALAM KITAB KAIFA NATA'AMAL AL-SUNNAH AL-NABAWIYYAH MA'ALIM WA DAWABIT
}

\section{HERMENETICS OF YUSUF AL-QARADAWI'S BOOK KAIFA NATA'AMAL AL-SUNNAH AL-NABAWIYYAH MA'ALIM WA DAWABIT}

Tabrani Tajuddin

Fakultas Ushuluddin dan Pemikiran Islam Universitas Islam Negeri Sunan Kalijaga Thabranitajuddin@gmail.com

\section{Neny Muthiatul Awwaliyyah}

Fakultas Ushuluddin dan Pemikiran Islam Universitas Islam Negeri Sunan Kalijaga nenyulthia@gmail.com

\begin{abstract}
Abstrak
Artikel ini fokus mengkaji hermenetika Yusuf Qardawi dalam memahami sebuah hadis. Artikel ini menarik untuk diikuti secara teliti paling tidak karena pengaruhnya dalam kajian Islam terkhusus dalam studi hadis. Yusuf Qardawi merupakan ulama kontemporer yang cukup berpengaruh. Hal ini disebabkan karena yusuf Qardawi mengajukan cara berfikir jalan tengah atau dia menyebutnya dengan metode berfikir moderat (al-wasatiyah) atau dalam bahasa lain tawazun (keseimbangan) yang mencoba memadukan konsep keilmuan Islam dengan Ilmu kealaman. Selain itu, artikel ini juga mencoba menulusuri hal yang mempengaruhi pemikiran yusuf Qardawi dalam studi keilmuannya yang meliputi tiga aspek. Pertama. Sejarah hidupnya; kedua, pengalaman pendidikan yang dia lalui; ketiga, konteks sosio-historis yang dia lalui.

Kata kunci: Hermeneutika, Hadis. Yusuf al-Qaradawi
\end{abstract}

\begin{abstract}
This article focuses on studying Yusuf Qardawi's hermenetics in understanding a hadith. This article is interesting to follow carefully at least because of its influence in Islamic studies especially in the study of hadith. Yusuf Qardawi was a contemporary cleric who was quite influential. This is because Yusuf Qardawi proposed a way of thinking middle ground or he called it a method of moderate thinking (al-wasatiyah) or in other languages tawazun (balance) which tried to integrate Islamic scientific concepts with science in depth. In addition, this article also tries to examine the things that influenced Joseph Qardawi's thinking in his scientific studies which covered three aspects. First. His life history; second, the educational experience that he went through; third, the sociohistorical context that he went through.
\end{abstract}

Keyword: Hermeneutic, Hadits, Yusuf al-Qaradawi 


\section{PENDAHULUAN}

Memahami hadis tidak semata soal mengetahui apa yang hendak disampaikan Nabi saw.tentang agama dan perilaku teladannya. Lebih dari itu, memahami hadis juga merupakan upaya aktualisasi ajaran agama dengan konteks kekinian dan menghidupkan semangat yang terkandung di dalam sunnah sebagai bagian dari kehidupan beragama. Otoritas hadis sebagai representasi sunnah justru menimbulkan polemiktersendiri ketika bersinggungan dengan kepentingan (subjektifisme). Sebab pemaknaan hadis sangat mungkin dipengaruhi oleh kehendak pembaca.

Setidaknya ada tiga hal yang menjadi fokus dalam kajian hadis saat ini, pertama, autensitas (ashliyah). Kedua, pemahaman (syarah). Ketiga, living hadis. Bila dibandingkan dengan sarjana Barat yang masih mempersoalkan autentisitas dan otoritas (hujjah), tren kajian hadis di kalangan sarjana muslim selangkah lebih maju dan dinamis karena mulai beralih dari kajian sanad ke kajian matan. ${ }^{1}$ Bahkan kajian living hadis. Berbagai pendekatan pun coba diterapkan, dan pada titik inilah hermeneutika mulai diperkenalkan, meski resepsi hermeneutis hadis sudah melahirkan ratusan kitab syarah sebelumnya. ${ }^{2}$

Penggunaan hermeneutika sebagai perangkat metode pemahaman teks keagamaan Islam baik al-Qur'an maupun hadis, bukan tanpa hambatan. Sebab pengadopsian teori hermenutik telah memunculkan pro dan kontra. Sebagian dari mereka ada yang menolak secara a priori, sebagian yang menerima secara totalitas, adapula yang mencoba menengahi perbedaan pandangan tersebut dengan menyatakan bahwa sebagian teori hermeneutika dipandang acceptable dalam kajian keislaman. ${ }^{3}$

Penerapan kajian teks terhadap nash agama baik al-Qur'an maupun hadis melalui pendekatan hermeneutik telah banyak memberikan kontribusi dalam perkembangan kajian hadis. Selain itu, hal ini juga dipengaruhi oleh minat dari para sarjana muslim yang mencoba mendekati al-Qur'an dengan mengkomparasikan teori yang berkembang di dunia Barat khususnya dalam kajian bahasa. Diantara mereka dari kalangan sarjana muslim yang menerima Hermeneutika, tentang bagaimana memahami ayat-ayat al-Qur'an dan Hadis Nabi, mereka adalah, antara lain, Fazlur Rahman, Mohammed Talbi, Nasr Hamid Abu Zayd, Muhammad Abid al-Jabiri, Aminah Wadud, Muhammad Sabeshtari, Muhammad Syahrur, Abdullah Saed, Nurcholis Madjid, Yusuf Qaradlawi dan Syuhudi Ismail. Para pemikir ini cukup familiar dengan teori-teori hermeneutika. Sebagai contoh, Fazlur Rahman yang mengusung metode doublemovement (Gerakan Ganda) dalam penafsiran alQur'an, telah banyak membaca karya-karya Hans-George Gadamer dan Emilio Betti. Muhammad Sabeshtari juga demikian, sangat kental dengan pemikiranpemikiran Ricoeur, misalnya, Familiaritas Abu Zayd dengan teori-teori

\footnotetext{
${ }^{1}$ Lihat misalnya, Jamal al-Banna, Nahw Fiqh Jadid;al-Sunnah wa Dauruha fi al-Figh alJadid (Kairo: Dar al-Fikr al-Islami, 1997)

${ }^{2}$ Teungku Muhammad Hasbi ash-Shiddieqy, Sejarah dan Pengantar Ilmu Hadis, h. 26-93.

${ }^{3}$ Sahiron Syamsuddin, Hermeneutika dan Pengembangan Ulumu Qur'an (Yogyakarta: Pesantren Nawesea Press, 2009), h. 1-3.
} 
hermeneutis dapat dilihat dalam pembahasannya terhadap sejarah pemikiran Hermeneutika Barat dalam bukunya Isykaliyyat al-Qira'at wa Aliyyat al-Ta 'wil. ${ }^{4}$

Dalam pembahasan artikel ini, penulis akan berfokus untuk lebih jauh mendalami dan mencoba menganalisis metode dalam memahami hadis yang dikembangkan oleh Yusuf Qardhawi. Hal ini juga penting bagi penulis. Mengingat bahwa beliau juga merupakan salah satu ulama kontemporer yang mempunyai kontribusi yang luar biasa dalam pengkajian ilmu keislaman.

\section{PEMBAHASAN}

Muhammad Yusuf Al-Qardhawi dilahirkan di desa Shafth Turaab, mesir bagian barat pada tanggal 9 september $1926 \mathrm{M}$. Beliau lahir dari keluarga yang tekun beragama, dibesarkan oleh pamannya sejak umur 2 tahun karena ayahnya meninggal dunia. ${ }^{5}$ Beliau juga mendapatkan perhatian yang cukup besar dalam hal pendidikan dari pamannya, sehingga oleh Yusuf al-Qaradawi dianggap sebagai ayahnya sendiri.

Pada usia lima tahun ia belajar menulis dan menghapal al-Qur'an oleh pamannya dan pada usia 10 tahun dia telah hapal al-Qur'an 30 Juz dengan fasih. Karena kefasihan dan kemerduan suaranya, ia sering diminta untuk menjadi imam yang usianya masih relatif muda dalam shalat-shalat Jahriyyah. Selanjutnya, beliau kemduian melanjutkan pendidikan Ibtidaiyah 4 tahun dan Sanawiyyah selama 5 tahun ditempuh Yusuf al-Qaradawi di Ma'had Tanta, Mesir. Pada usia lima belas tahun ia sudah membaca buku-buku mahasiswa. Buku tasawwuf pertama yang ia baca adalah Minhaj al- 'Abidin yang beliau peroleh dari pamannya, Syaikh Tantawi Murad. Buku tasawwuf kedua yang ia baca adalah Ihya' 'Ulum al-Din, yang ia pelajari dari seorang murid ulama Mesir, Syaikh Muhammad Abu Syah. Yusuf alQaradawi sangat terkesan hingga badannya bergetar ketika belajar Ihya' ulum alDin karena isinya yang sangat mengagumkan. Beliau pun menyaksikan kesungguhan orang-orang disekelilingnya yang sangat sungguh-sungguh dalam menjalankan ajaran tasawuf, sehingga ajaran tersebut sangat melekat dalam jiwanya. ${ }^{6}$

Selain tertarik dengan buku-buku Tasawuf, Yusuf al-Qaradawi juga sangat tertarik dengan buku-buku sastra, seperti karya al-Manfaluthi, Al-Nazarat,al-'Ibrat dan kisah yang lainnya. Selain itu ia juga membaca al-'Iqd al-Farid, karya tentang Sastra yang ditulis oleh Ibn 'Abd Rabbih (w. 328 H/940 M) ${ }^{7}$ Yusuf al-Qaradawi menyelesaikan studi di Fakultas Ushuluddin Universitas al-Azhar, Kairo pada tahun 1952/1953. Kemudian melanjutkan pendidikannya ke jurusan Bahasa Arab selama dua tahun dengan mendapatkan predikat terbaik di antara lima ratus mahasiswa. $^{8}$

\footnotetext{
${ }^{4}$ Kurdi dkk, Hermeneutika al-Qur'an dan Hadis (Cet. I; Yogyakarta: eLSAQ Press, 2010), h. vi.

${ }^{5}$ Sutopo, Analisis Hermeneutik atas Pemikiran Yusuf Qardhawi tentang Hadis-Hadis Ekonomi, (Iqtishadia, Vol. 8, No. 2, September 2015.

${ }^{6}$ Suryadi, Metode Kontemporer Memahami Hadis Nabi, Cet. I (Yogyakarta: Teras, 2008), h. 42

${ }^{7}$ Suryadi, Metode Kontemporer Memahami Hadis Nabi, , h. 42

${ }^{8}$ Abdul Aziz Dahlan (dkk.), Ensiklopedia Hukum Islam..h. 1448.
} 
Pada tahun 1960 Yusuf al-Qaradawi melanjutkan ke Pascasarjana (Dirasah al-'Ulya Universitas al-Azhar, Kairo dengan berkonsentrasi pada jurusan TafsirHadis atau jurusan Aqidah-Filsafat. Setelah itu ia melanjutkan studinya ke Program Doktor dan menulis disertasi yang berjudul Fiqh al-Zakah (Fikih Zakat) ditempuh dalam waktu dua tahun, menurutnya waktu dua tahun ini terlambat karena tidak sesuai dengan waktu yang telah diperkirakan sebelumnya, karena sejak tahun 1968 sampai 1970 beliau ditahan oleh pemerintah militer Mesir atas tuduhan mendukung pergerakan al-Ikhawan al-Muslimin. ${ }^{9}$

Setelah keluar dari tahanan beliau kemudian hijrah ke Daha, Qatar dan dari sinilah ia kemudian berjumpa dengan 'Abd al-Mu'is al-Satar, beliau merupakan teman seperjuangan Yusuf Qaradhawi dalam mendirikan Madarasah Ma'had alDin (Institut Agama) yang cikal bakal lahirnya Fakultas Syari'ah, Qatar yang berkembang dengan beberapa fakultas dan akhirnya menjadi sebuah Universitas Qatar yang didirikan bersama dengan Ibrahim Khadim. Yusuf al-Qaradawi saat itu yang menjadi kepala dekan Fakultas Syari'ah. ${ }^{10}$

Sikap moderat dan keterbukaan beliau terhadap perkembangan ilmu pengetahuan modern yang dipegangi oleh Yusuf Qardawi juga terbawa dalam lingkup keluarga beliau. Hal ini dapat dilihat dari beragam pendidikan anakanaknya. Dari tujuh anaknya, hanya satu yang kemudian menempuh pendidikan di Universitas Darul 'Ulum Mesir dan menempuh pendidikan agama, sedangkan yang lainnya, mengambil pendidikan dan semuanya ditempuh diluar negeri.

Yusuf al-Qaradawi juga cukup tekenal sebagai ahli hukum dan ahli politik. Dalam hal ini pemikiran beliau cukup dipengaruhi oleh Syaikh Hasan al-Banna, baginya kekaguman beliau terhadap Syaikh Hasan al-Banna adalah ulama yang cukup konsisten dalam menyuarakan ajaran Islam, tanpa terpengaruh oleh paham nasionalisme dan sekularisme yang dibawa oleh penjajah Mesir dan dunia Islam. Sedangkan wawasan Ilmiahnya lebih banyak dipengaruhi oleh ulama-ulama alAzhar. ${ }^{11}$

Meskipun dalam perjalan intelektual beliau lebih dekat kepada tokoh-tokoh dari kelompok Ikhwann al-Muslimun, seperti Syaikh Hasa al-Banna Muhammad al-Gazali, al-Bahi' al-Khauli, Muhammad Abduh (1849-1905) dan Sayyid Muhammad Rasyid Rida (1865-1935) cukup terkenal dengan anti kefanatikan dan taklid buta. Selain itu ia juga mengagumi Sayuid Sabiq, pengarang kitab Fiqh alSunnah. Tokoh lain yang juga sangat penting dalam bagi Yusuf al-Qaradawi adalah Ibn Taimiyah (w. 728 h./ 1328 M) dan Ibn Qayyim (W. 751 h/1350).

Walaupun Yusuf al-Qaradawi banyak mengagumi pemikiran tokoh tersebut di atas, hal ini tidak menjadikan beliau bertaklid buda kepada mereka begitu saja, dalam beberapa pengantar dalam bukunya ia kerap kali mengegaskan bahwa ia tidak pernah terikat dengan mazhab, tradisi maupun pendapat seorang ulama tertentu, meskipun secara formal ia mempelajari mazhab Hanafi.

\footnotetext{
${ }^{9}$ Abdul Aziz Dahlan (dkk), Ensiklopedia Hukum Islam, h. 1448

${ }^{10}$ Suryadi, Metode Kontemporer Mehamahami Hadis Nabi. h. 44.

${ }^{11}$ Abdul Aziz Dahlan (dkk), Ensiklopedia Hukum Islam, h. 1448
} 


\section{Karya-Karya Yusuf al-Qardhawi}

Yusuf al-Qardhawi merupakan seorang ulama dan cendekiawan muslim yang ahli dalam berbagai disiplin ilmu, berwawasan luas dan cukup produktif. Tulisannya tidak hanya dalam buku-buku saja, tetapi juga melalui berbagai media. Berbagai judul telah ia hasilkan melalui karya-karyanya, dan telah diterjemahkan ke dalam berbagai bahasa oleh kaum Muslim di seluruh dunia. ${ }^{12}$

Karya-karya Yusuf al-Qardhawi antara lain, Min Fiqh al-Daulah fi al-Islam, Makanatuha, Ma'alimuha, Thabi'atuha, Mauqifuha, min al Dimaqratiyah wa alTa 'addudiyah wa al-Maar'ah wa Ghairu al-Muslimin. ${ }^{13}$ kitab ini merupakan respon terhadap isu-isu sentral yang berkenaan dengan isu Negara Islam, Yusuf Qardhawi dalam buku ini mencoba memberikan argument bagaiaman kedudukan agama Islam? Bagaiaman hukum mendirikannya? Apakah Negara Islam merupakan negara madani? Bagaimana cara menolak prasangka yang mengatakan bahwa negara Islam merupakan negara agama yang harus ditegakkan berdasarkan hak Allah? Bagaimana pandangan Islam terhadap sistem demokrasi, multipartai, dan non-Muslim? dan masih banyak lagi topic-topik penting lainnya yang dibahas dalam buku ini.

Selain itu, sebagai seorang ulama kontemporer, Yusuf al-Qaradawi juga memilki banyak karya ilmiah dalam berbagai disiplin ilmu pengetahuan yang tersebar dalam beberapa buku beliau maupun artikel yang telah diterbitkan diberbagai perguruan tinggi dan pesantren. Karya-karya tersebut antara lain. ${ }^{14}$ A'da'al-Halal-Islami, Adwa' ala Qadiyah al-Takfir baina al-Gulah wa alMuqassirin,Aina al-Halal?,Akhlaq al-Islam fi Dani al-Kitab wa al-Sunnah, 'Alam wa al-Tagiyyah,'Aqaid al-Islam fi Dani al-Kitab wa al-Sunnah, Al-'Aqiyyat alDiniyyah wa al-Hal al-Islami, Al-Aql wa al-'Ilm fi al-Qur'an al-Karim, Aulawiyyat al-Harakah al-Islamiyyah fi al-Marhalah al-Qadimah (1990), 'Awamil al-Sa'ah wa al-Murunah fi al-Syari'ah al-Islamiyyah, Ba'I al-Murabahah li al-Amri bi alSyarra' (1983), Bayyinat al-Hall al-Islami wa Syubhat al-Ilmaniyyin wa alMutagarribin (1988), Dars al-Nukbah al-Saniyyah, Daur al-Qalim wa al-Akhlaq fi al-Iqtisad, Al-Din fi 'Asri al-'Ilm, Durus fi al-Tafsir "Tafsir Surah al-Ra'd", Fatawa li al-Mar'ah al-Muslimah, Fatawa Mu'asirah, Al-Fatawa baina al-Indibat wa al-Tasayyub (1988), Fawaid al-Bunuk Hiya al-Riba al-Haram (Cet.III. 1994), Fi Fiqh al-Aulawiyyat "Dirasah al-Jadidah Fi Dau' al-Qur'an wa al-Sunnah", Al-Fiqh al-Islami baina al- 'Asalah wa al-Tajdid, Fiqh al-Zakah, Gair al-Muslimin fi al-Mujtama' al-Islami, Al-Halal wa al-Haram fi al-Islam (1976), Al-Hall alIslami wa Syubhat al-Murtabin wa al-Musyakkin, Haqiqah al-Tauhid, Al-Hayah al-Rabbaniyyah wa al-'Ilm, Al-Hall al-Islami Faridah wa Darurah, Al-Hulul alMusaturadah wwa Kaifa Jannat 'ala Ummatina, Al-'Ibadah fi al-Islam, Al-Ijtihad fi al-Syari'ah al-Islamiyyah (1985), Al-Ijtihad al-Mu'asirah baina al-Indibat wa al-Infirad, Al-Iman wa al-Hayah, Al-Imam al-Gazali baina Madihiyyah wa

\footnotetext{
${ }^{12}$ Sucipto Heri, Ensiklopedia Tokoh Islam, dari Abu Bakar sampai Al-Qardhawi, h. 338.

${ }^{13}$ Yusuf al-Qardhawi, Min Fiqh al-Daulah fi al-Islam, Makanatuha, Ma'alimuha, Thabi'atuha, Mauqifuha, min al Dimaqratiyah wa al-Ta'addudiyah wa al-Maar'ah wa Ghairu alMuslimin (Cairo: Dar al-Syuruq, 1997)

${ }^{14}$ Suryadi, Metode Kontemporer Memahami, h. 53-57
} 
Naqidiyyah (1987), Al-Islam Hadarah al-Gadd, Al-Islam wa al-Fann, Al-Islam wa al-'Ilmaniyyah Wajhan lo Wajhin, Jail al-Nasr al-Mansyud, Jarimah al-Riddah wa 'Uqubah al-Murtad fi Dau' al-Qur'an wa al-Sunnah, Kaifa Nata'amal ma'a a'Qur'an al-Karim, Kaifa Nata 'amal ma'a al-Sunnah al-Nabawiyyah Ma'alim wa Dawabit (1989), Al-Khasaits al- 'Ammah li al-Islam (1977), Khatubah al-syaikh alQaradawi, Likai tunja Mu'assasah al-Zakah, Liqa'at wa Mahawirat Haula Qadayya al-Islam wa al-'Asr (1922), Al-Madkhal li Dirasah al-Syari'ah alIslamiyyah, Madkhal li Ma'rifah al-Syari'ah al-Islamiyyah, Malamih al-Mujtami' al-Muslim al-laz Nansyuduh, Markaz al-Mar'ah fi al-Hayah al-Siyasiyyah alIslamiyyah, Mauqif al-Islam min Ilham wa al-Kasyf wa al-Ru'yah wa min Tama'im wa al-Kahanah wa al-Ruqa (1994), Min Ajli al-Sahwah Rasyidah, Min Fiqh alDaulah fi al-Islam, Al-Muntaqamin al-Targib wa al-Tahrib, Al-Murji'iyyah al'Ulya fi al-Islam, Al-Muslimu Qadimun, Musykilah al-Faqr wa Kaifa 'Alajaha alIslam, Nafaha wa Lafahat, Al-Nas wa al-Haq, Al-Niqab lo al-Mar'ah, Nisa' Mu'minat, Al-Niyyah wa al-Ikhlas, Qutuf Daniyyah min al-Kitab wa al-Sunnah, AlRasul wa al-'Ilm, Qadiyah Mu'asirah 'ala Bisat al-Bahs, Risalah al-Azhar baina al-Ams wa al-Yaum wa al-Gadd, Al-Sabr fi al-Qur'an al-Karim, Al-Sahwah alIslamiyyah baina Ikhtilaf al-Masyru' wa al-Tafruq al-Mazmun (1990), Al-Sahwah al-Islamiyyah baina al-Juhud wa al-Tatarruf, Al-Sahwah al-Islamiyyah wa Humum al-Watan al- 'Arabi al-Islami, Al-Siyasah al-Syar'iyyah, Al-Sunnah Masdar li alMar'ah wa al-Hadarah (1997), Al-Syaikh al-Gazali Kama 'Araftuhu rihla Nisf alQarn (1995), Syari'ah a;-Islam, Syumul al-Islam, Taisir al-Fiqh...Fiqh al-Siyam, Al-Tarbiyyah al-Islamiyyah wa Madrasah Hasan al-Banna (Cet.III.1992), AlTatarruf al-'Ilman fi Muwajahah al-Islam (2000), Al-Taubah ila Allah (1998), AlTawakkal, Saqafah al-Daiyyah, Al-Saqafah al-'Arabiyah al-Islamiyyah baina al'Asalalah wa al-Mu'asirah, Al-Ummah al-Islamiyyah Haqiqah la Wahm, Al-Waqt fi Hayah al-Muslim (Ct.VI.1994), Wujud Allah, Yusuf al-Siddiq "Masrihiyyah Sya'riyyah", Z ahirah al-Gulw fi al-Takfir.

\section{Hermeneutika Yusuf al-Qaradawi}

\section{Pandangan Yusuf al-Qaradawi tentang Sunnah}

Setiap kajian yang serius tentang al-Sunnah harus berangkat dari sebuah pertanyaan mendasar yang perlu dijawab secara jelas dan sempurna. Pertanyaan ini dapat diungkapkan sebagai berikut:

"Apakah seluruh perkataan, gerakan, dan perilaku Nabi saw yang tidak terkait dengan dasar-dasar agama, hudud, ibadah, dan masalah-masalah ghaib, jika benar termasuk wahyu atau ijtihad? Pertanyaan inilah yang mencoba dijawab Yusuf al-Qardawi dalam beberapa karya beliau dengan mempetakan sunnah menjadi tiga bagian utama.

Pertama, mengenai aspek yuridis (tasyri') pada sunnah. Poin ini tercakup pembahasan tentang Sunnah sebagai tasyri' dan bukan tasyri', Sunnah sebagai tasyri' umum dan khusus, Sunnah sebagai ketetapan tasyri' yang abadi dan insindentil. Dalam hal ini Yusuf al-Qaradawi berusaha bersikap moderat antara kaum ekstrim dalam apresiasi Sunnah dan kaum yang melecehkan Sunnah.

Kedua, mengenai Sunnah sebagai sumber ilmu pengetahuan, baik ilmu pengetahuan agama yang berhubungan dengan hal-hal yang ghaib yang sumber satu-satunya adalah wahyu; yaitu persoalan yang terkait dengan Allah, Malaikat, 
Kitab dan Rasul-nya; tentang hari Akhir, Syurga, dan Neraka, Kiamat dan tandatandanya, serta peristiwa-peristiwa akhir zaman yang pembahasannya disertai dengan fokus terhadap berita-berita Sunnah yang menggembirakan tentang masa depan ummat Islam (mubasysyirat).

Ketiga, tentang sunnah sebagai sumber peradaban, yang mencakup dua bidang yang besar, yaitu Sunnah dan fikih peradaban serta Sunnah sebagai perilaku peradaban.

Berdasarkan perspektif ini, kita dapat memahami bahwa kajian Yusuf alQaradawi terhadap hadis tidak hanya pada aspek sanad, matan dan kesahihan hadis tapi juga menggunakan pendekatan historis dan sosiologis. Melalui pendekatan historis dan sosiologis, hal ini memungkinkan para penafsir untuk melihat kompleksitas dan keadaan Nabi sebagai author dilihat dari otoritas dan kedudukan Nabi saw. ${ }^{15}$

\section{Kedudukan Sunnah dalam Islam}

Sunnah sebagaimana dinyatakan oleh Yusuf al-Qaradawi adalah tafsir aplikatif (al-Tafsir al- 'amali) terhadap al-Qur'an dan implementasi ajaran Islam secara faktual dan ideal. Oleh karena itu sunnah sebagai implementasi ajaran Islam adalah merupakan sebuah metode yang dibagi menjadi tiga macam, antara lain:

a. Metode yang Komprehensif (ManhajSyumuli)

Adalah metode yang bersifat universal untuk kehidupan manusia seluruhnya, secara panjang, lebar dan dalam. Maksudnya adalah segala aspek yang mencakup kehidupan manusia dari sejak lahir hingga meninggal dunia, bahkan sejak periode janin hingga kehidupan setelah mati. Dalam hal ini juga termasuk dari aspek poin ini adalah mencakup semua aspek kehidpan, dimana berjalan bersamanya petunjuk Nabi di dalam ruman, pasar, masjid, jalan, pekerjaan, berhubungan dengan Allah, berhubungan dengan diri sendiri, berhubungan dengan keluarga, baik sesama muslim ataupun yang bukan muslim, bahkan dengan sesame manusia, binatang dan benda mati sekalipun. Poin ini juga mencakup eksistensi kedalaman manusia, mencakup tubuh, akal dan ruh. Juga mencakup lahir batin, ucapan, perbuatan dan niat.

b. Metode Keseimbangan (Manhaj Tawazun)

Ia adalah metode yang mencoba memahami hadis dengan menyeimbangkan aspek ruh dan tubuh, antara akal dan hati, antara dunia dan akhirat, antara ideal dan realita, antara teori dan praktekm antara yang gaib dan nyata, antara kebebasan dan tanggung jawab, antara individu dan masyarakat, antara mengikuti dan berkreasi

c. Metode yang Memudahkan (Manhaj Taisir)

\footnotetext{
${ }^{15}$ Ulama yang pertama kali memahami kandungan hadis Nabi dengan menghubungkan fungsi Nabi saw. adalah Imam Syihab al-Din al-Qarafi (w. 694 H) dalam kitabnya yang berjudul: al-Furuq. Dalam kitab tersebut, al-Qarafi melakukan kajian tentang ucapan dan perbuatan Rasulullah saw. beserta perbedaan kondisinya, anatara beliau sebagai pemimpin, hakim dan pemberi fatwa atau penyampai ajaran dari Allah swt. Hal itu berpengaruh pada keumuman hukum dan kekhususan, keuniversalan atau ketemporerannya. Lihat. Arifuddin Ahmad, Metodologi Pemahaman Hadis: Kajian Ilmu Ma'ani al-Hadis (Makassar: Alauddin University Press, 2013) hal. 127
} 
Karakteristik dari metode ini adalah juga mudah dan toleran. Sehingga dalam sunnah Nabi Muhammad saw. ini tidak ada yang menyulitkan manusia dalam kehidupan beragamanya, atau membuat mereka susah payah dalam kehidupan dunianya.

\section{Metode Pemahaman Hadis Yusuf al-Qaradawi}

Dalam kitab Kaifa Nata'amal ma'a al-Sunnah al-Nabawiyyah Ma'alim wa Dawabit yang juga merupakan sumber kajian dalam penulisan ini Yusuf alQaradawi mengintrodusir delapan kriteria dalam memahami hadis;

1. Memahami hadis sesuai petunjuk al-Qur'an

Memahami hadis sesuai petunjuk al-Qur'an didasarkan pada argument bahwa al-Qur'an adalah sumber utama yang menempati tempat tertinggi dalam keseluruhan system doctrinal Islam. Sedangkan hadis adalah penjelas atas prinsip al-Qur'an. Oleh karena itu, makna hadis dan signifikansi kontekstualnya tidak bisa bertentangan dengan al-Qur'an. ${ }^{16}$

Jika terdapat pertentangan, maka hal itu bisa terjadi karena hadis tersebut tidak sahih, atau pemahamannya yang tidak tepat, atau yang diperikirakan sebagai pertentangan itu bersifat semu dan bukan hakiki. Jika hal itu terjadi, maka tugas seorang muslim adalah mentawaqufkan hadis yang dilihatnya bertentangan dengan ayat al-Qur'an yang muhkam selama tidak ada penafsiran yang dapat diterima. Contoh dari metode ini adalah Hadis Gharaniq. Hadis ini adalah hadis palsu yang menurut Yusuf al-Qaradawi harus ditolak karena bertentangan dengan al-Qur'an QS. Al-Najm [53]:19-23:

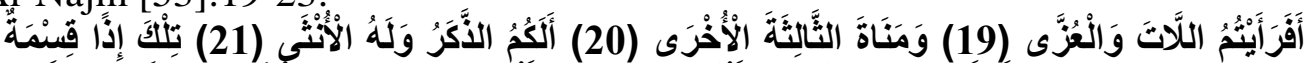

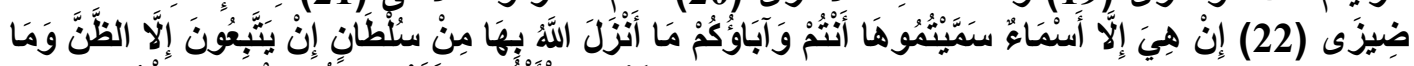

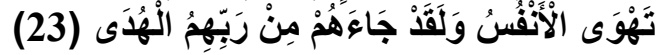

Terjemahnya:

Maka apakah patut kamu (hai orang-orang musyrik) menganggap Lata dan Uzza. [19] mana yang ketiga, yang paling kamu terkemudian (sebagai anak perempuan Allah)? [20] apakah (patut) untuk kamu (anak) laki-laki dan untuk Allah (anak)perempuan? [21] yang demikian itu tentulah suatu pembagian yang tidak adil. [22] itu tidak lain hanyalah nama-nama yang kamudan bapalk-bapak kamu mengadakannya; Allah tidak menurunkan sesuatu keteraganpun untuk (menyembah) Nya. Mereka tidak lain hanyalah mengikuti sangkaan-sangkaan, dan apa yang diingini oleh hawa nafsu mereka dan sesungguhnya telah datang petunjuk kepada mereka dari Tuhan mereka [23].

Ketika Nabi masih di Mekkah membaca surah ini pada ayat 19 dan 20, maka تلك الغرانيق العلى وأن “ menurut riwayat itu setan menambahkan melalui lidah Nabi

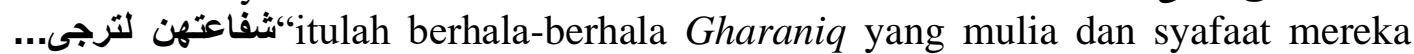
sungguh diharapkan. ${ }^{17}$

\footnotetext{
${ }^{16}$ Yusuf al-Qarad awi, Kaifa Nata'amal Ma'a al-Sunnah al-Nabawiyyah, terj. Muhammad al-Baqir (Cet. IV; Bandung: Kaarisma, 1995), hal. 27

${ }^{17}$ Yusuf al-Qarad awi, Kaifa Nata'amal Ma'a al-Sunnah al-Nabawiyyah, terj. Muhammad al-Baqir , hal. 93
}

al-Mutsla, Volume 3, No 1, 2020 
Yusuf al-Qarad awi menyangkal hadis ini, menurutnya, sungguh mustahil dalam runtutan ayat-ayat yang berisi penyangkalan dan kecaman keras terhadap patung-patung itu terdapat sisipan yang memujinya.

2. Menghimpun Hadis-hadis yang Setema

Upaya memahami sunnah, menurut Yusuf al-Qaradawi, dapat dilakukan dengan menghimpun hadis-hadis sahih yang berkaitan dengan suatu tema tertentu. Setelah penghimpunan hadis-hadis setema. Langkah berikutnya adalah mengembalikan kandungannya yang mutasyabih kepada yang muhkam dan menafsirkan yang 'am dengan yang khash.

Metode ini merupakan keniscayaan oleh karena hadis berfungsi sebagai penafsir al-Qur'an dan penjelas makna-maknanya dengan merinci, menafsirkan, dan membatasi apa yang dinyatakan dalam al-Qur'an, maka sudah barang tentu hal ini kemudian diterapkan dalam menafsirkan hadis dengan hadis.

Contoh yang diangkat oleh Yusuf al-Qarad awi untuk memperjelas upaya ini adalah tema tentang hukum memakai sarung sampai di bawah mata kaki. Langkah pertama adalah mengemukakan beberapa hadis tentang celaan terhadap orang yang mengenakan sarung sampai di bawah mata kaki. Kemudian menyebutkan hadishadis yang berkaitan dengan orang-orang yang mengenakan sarung sampai di bawah mata kaki tanpa dibarengi kesombongan. Selanjutnya ia adalah menampilkan hadis-hadis yang menjelaskan tentang celaan terhadap orang yang menjulurkan sarung atau pakainnya karena kesombongan. ${ }^{18}$

Disamping itu, Yusuf al-Qaradawi juga mengungkapkan penjelasanpenjelasan dari berbagai ulama, di antaranya Ibn Hajar dan al-Nawawi. Pada akhirnya menyimpulkan dengan membawa hadis-hadis yang dalalahnya muqayyad, bahwa ancaman terhadap perbuatan menjulurkan sarung itu terbatas kepada orang yang melakukannya karena kesombongan dan kebanggan diri saja. Jika menjulurkan sarung karena adat kebiasaan maka tidak termasuk sasaran ancaman. ${ }^{19}$

3. Penggabungan antara Hadis-hadis yang Tampak Bertentangan

Pada dasarnya nash syari'at tidak mungkin saling bertentangan, demikian prinsip yang dipegang olehnya. Pertentangan yang tampak kemungkinan dalam dataran lahiriyyahnya semata dan bukan pada kenyataan yang hakiki. Jika hal ini terjadi, maka penggabungan lebih utama daripaa pentarjihan. Karena tarjih berarti mengabaikan salah satu dari duanya. ${ }^{20}$ wanita:

Kasus hadis yang yang diketengahkan adalah tentang ziarah kubur bagi

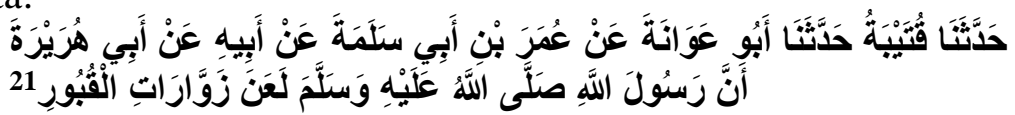

${ }^{18}$ Hadis-hadis yang dimunculkan adalah hadis riwayat Muslim dari Abi Dzar, riwayat alثلاثة لا يكلمهم : Bukhari dari Abu Hurairah, Juga Abdullah bin Umar. Hadis riawayat Muslim berbunyi الله يوم القيامه المناى الذى لا يعطى شيئا إلا منه. و المنفق سلعته بالحف الكاذب و المسبل إزاره

${ }^{19}$ Yusuf al-Qaradawi, Kaifa Nata'amal Ma'a al-Sunnah al-Nabawiyyah, terj. Muhammad al-Baqir hal. 107-112

${ }^{20}$ Yusuf al-Qaradawi, Kaifa Nata'amal Ma'a al-Sunnah al-Nabawiyyah, terj. Muhammad al-Baqir hal. 117-118

${ }^{21} \mathrm{Abu}$ 'Isa Muhammad bin 'Isa al-Thurmudziy,al-Jami' al-Kabir (Beirut: Dar al-'Arabiy 
Artinya:

Dari Abu Hurairah ra. Sesungguhnya Rasulullah saw. melaknat wanitawanita yang terlalu sering berziarah kubur (HR. Tirmidzi)

Hadis itu bertentangan dengan hadis yang membolehkan ziarah kubur secara umumbها نهيتكم عن زيارة القبور فزروها ... Hadis yang tampak bertentangan itu, menurut Yusuf al-Qaradawi dengan menukil pendapat al-Qurthubi, bahwa hadis yang melarang tersebut dapat dikompromikan, yakni hadis yang melarang perempuan berziarah kubur dikarenakan zawwarat terlalu sering berziarah kubur sehingga memungkinkan terabaikannya kewajiban yang lain. ${ }^{22}$

4. Memahami Hadis Sesuai Latar Belakang, Situasi, Kondisi dan Tujuan

Untuk memahami hadis Nabi, dapat dengan memperhatikan sebab-sebab khusus yang melatarbelakangi diucapkannya sebuah hadis, atau terkait dengan 'illah tertentu yang dinyatakan dalam hadis tersebut atau dari kejadian yang melingkupinya. Hal ini mengingat hadis Nabi merupakan penyelesaian terhadap problem yang bersifat lokal, particular, dapat melakukan pemilihan antara apa yang umum, sementara dan abadi, dan atara yang universal dengan partikular.

Dalam pandangan Yusuf al-Qaradhawi, jika kondisi telah berubah dan tidak ada 'illah lagi, maka hukum penggunaan suatu nash akan gugur. Pun demikian dengan yang hadis yang belandaskan suatu kebiasaan bersifat temporer yang berlaku pada masa Nabi dan mengalami perubahan pada masa kini, maka yang dipegangi adalah maksud yang dikandungya dan bukanlah pengertia harfiahnya. ${ }^{23}$

Dapat dicontohkan dengan hadist tentang urusan dunia. أنتم أعلم بأمر دنياكم Hadis ini menurutnya tidak bisa dipahami dari 'ibarah al-nash, tetapi harus diapahami dari sebab khusus munculnya hadis, yakni berkenaan dengan penyerbukan kurma. Suatu ketika Nabi berpendapat tentang penyerbukan kurma. Para sahabat menilainya sebagai wahyu dan mengikuti perkataan Rasul namun hasilnya berdampak buruk pada hasil panen mereka. Kemudian muncullah sabda ini. Hadis ini dipahami dalam konteks tersebut, dan tidak berarti semua urusan dunia dapat terbebas dari tuntutan agama. Karena, al-Qur'an dan hadis memberi petunjuk pula tentang berbagai persoalan dunia. Selain itu, hadis ini menunjukkan bahwa Nabi pengakui dan menerima hasil percobaan dalam bidang pertanian dan bidang lain. ${ }^{24}$

5. Membedakan antara Sarana yang Berubah-ubah dan Sasaran yang Tetap

Makan substansial atau tujuan hakiki teks hadis sangat penting untuk diketahui dan dipegang. Karena, tujuan hakiki bersifat tetap sedangkan prasarana menuju tujuan itu adakalanya berubah dengan adanya perubahan zaman, kebiasaan, lingkungan. Inilah yang sering rancu dikalangan kaum muslimin, antara tujuan atau sarana seringkali tumpang tindih dengan prasarana.

\footnotetext{
al-Islamiy, 1998), hal. 359

${ }^{22}$ Yusuf al-Qaradawi, Kaifa Nata'amal Ma'a al-Sunnah al-Nabawiyyah, terj. Muhammad al-Baqir hal. 120-122

${ }^{23}$ Yusuf al-Qaradawi, Kaifa Nata'amal Ma'a al-Sunnah al-Nabawiyyah, terj. Muhammad al-Baqir hal. 131-132

${ }^{24}$ Yusuf al-Qaradawi, Kaifa Nata'amal Ma'a al-Sunnah al-Nabawiyyah, terj. Muhammad al-Baqir , hal. 133-134
} 
Sebagai contoh hadis tentang siwak. Penyebutan siwak dengan kayu arak oleh Nabi tidaklah mengikat agar menggunakan dengan alat itu. sebab yang menjadi tujuan dari hadis tersebut adalah terjaganya kebersihan dan kesehatan gigi dan mulut. Sedangkan mengenai alat yang digunakan tergantung kondisi suatu tempat tertentu dan waktu tertentu. ${ }^{25}$

6. Membedakan antara Ungkapan Haqiqah dengan Majaz

Menurut Yusuf al-Qaradawi, pemahaman berdasarkan majaz terkadang merupakan suatu keharusan karena tidak, akan terjebak dalam kekeliruan. Hadis yang tidak bisa dipahami secara tekstual, bisa dita'wilkan dengan alasan yang kuat. Sebaliknya, pemahaman hadis yang hanya sesuai dengan susunan lahiriyahnya akan tertolak jika bertentangan dengan konklusi akal yang jelas atau hukum syariah yang benar. ${ }^{26}$

Contoh ketika memahami hadis tentang keutamaan makan sahur. Ulama bathiniyyah mengartikan kata tasahhara dengan istighfara. Pemahaman seperti ini menurut Yusuf al-Qaradawi tidak dapat diterima melihat adanya hadis lain yang mendukung arti makan sahur sebenarnya. ${ }^{27}$

7. Membedakan yang Gaib dengan yang Nyata

Jika menilik kandungan hadis, ada banyak hadis yang berbicara tentang halhal gaib. Diantaranya, mengenai makhluk-makhluk yang tidak dapat diindera, alam kubur, kehidupan akhirat termasuk mizan, mahsyar, hisab. Hadis-hadis yang berkualitas sahih mengenai hal yang semacama ini, bagi Yusuf al-Qaradawi tetaplah wajib diterima. Tidak dibenarkan menolak hadis-hadis tersebut hanya karena tak bisa dialami oleh manusia (pengaaman empiris). Selama masih dalam batas kemungkinan menurut akal, tetaplah bisa diterima. ${ }^{28}$

Yusuf al-Qaradawi sependapat dengan Ibn Taimiyyah dalam hal menghindari ta'wil terhadap hal-hal yang berkaitan dengan alam gaib ini. Ia mengkritisi pemikiran dan pemahaman Mu'tazilah yang berusaha menganalogikan antara sesautu yang gaib dengan yang nyata. Contoh yang dikemukakan adalah persoalan ru'yah. Menurutnya, melihat Allah adalah mungkin walaupun cara dan hakikatnya tidak dapat dijangkau oleh akal. Ia membantah pandangan Mu'tazilah yang memusatahilkan terjadinya ru'yah Allah berdasar argument bahwa mereka telah melakukan kesalahan yaitu menganalogikan antara alam gaib dengan alam nyata, didasarkan pula pada QS. Al-Qiyamah tentang seorang mukmin yang melihat Tuhan mereka sejelas mereka melihat bulan purnama. ${ }^{29}$

\footnotetext{
${ }^{25}$ Yusuf al-Qarad`awi, Kaifa Nata'amal Ma'a al-Sunnah al-Nabawiyyah, terj. Muhammad al-Baqir, hal. 147-148

${ }^{26}$ Yusuf al-Qaradawi, Kaifa Nata'amal Ma'a al-Sunnah al-Nabawiyyah, terj. Muhammad al-Baqir, hal. 167

${ }^{27}$ Yusuf al-Qaradawi, Kaifa Nata'amal Ma'a al-Sunnah al-Nabawiyyah, terj. Muhammad al-Baqir, hal. 185.

${ }^{28}$ Yusuf al-Qaradawi, Kaifa Nataamal Ma'a al-Sunnah al-Nabawiyyah, terj. Muhammad al-Baqir, hal. 188-189

${ }^{29}$ Yusuf al-Qaradawi, Kaifa Nataamal Ma'a al-Sunnah al-Nabawiyyah, terj. Muhammad alBaqir,hal. 193-194
} 


\section{Memastikan Makna Kata-kata dalam Hadis}

Memastikan makna dan konotasi kata-kata sangat penting dalam memahami sebuah hadis. Sebab, konotasi kata-kata tertentu adakalanya berubah dari suatu masa ke masa lainnya, dari suatu lingkungan ke lingkungan lainnya. ${ }^{30}$

Satu contoh kata dalam hadis yang telah berubah konotasinya yaitu kata tashwir (pembuata gambar). Juga hadis-hadis yang mengancam para musawwir dengan siksa yang amat pedih. Masa kini, katab tashwir digunakan untuk menyatakan suatu kegiatan pengambilan gambar atau kamera. Tekhnologi fotografi ini belum ada dan tidak dikenal pada masa Nabi, maka tidak mungkin ditujukan pada ahli foto. Jadi, memasukan ancaman kepada ahli foto tidaklah tepat. Dan inilah yang membuat Yusuf al-Qaradawi berhati-hati dalam memastikan makna suatu kata tertentu dalam hadis.

\section{Analisis Hermeneutika Hadis Yusuf al-Qaradawi}

Dalam pembahasan sebelumnya telah dijelaskan beberapa langkah Yusuf al-Qaradawi dalam memahami hadis. Selanjutnya penulis memfokuskan kepada beberapa point inti untuk menganalisis metode hermenetika Yusuf Al-Qaradaawi. Dalam hal ini penulis membaginya dalam tiga kelompok, sebagai berikut:

a. Memahami aspek bahasa

Dalam hal ini pemahaman terhadap hadis menurut Yusuf al-Qaradawi sangat mungkin dipengaruhi oleh faktor Subjektifitifisme (zatiyyah) dan faktor waktu dan tempat (mauduiyyah) penafsir. Bagi Yusuf al-Qaradawi sendiri mengemukakan bahwa pemahaman terhadap hadis cukup berbahaya bila para penafsir mencoba mengalihkan makna hakiki ke makna majazi. Karena pada dasarnya pemahaman terhadap sebuah teks harus lebih mengedepankan makan lahiriyah kecuali ada indikasi (qarinah). Atau atas petunjuk tertentu yang mengharuskan mengalihkan makna dari makan literalnya.

Meski cukup terbuka terhadap pendekatan kebahasaan dalam memahami teks hadis, Yusuf al-Qaradawi juga memberi batasan. Berdasarkan kehati-hatian dalam memahami sebuah nash, terutama bagi para penafsir yang ingin mencoba mendekati teks dengan pendekatan kebahasaan. Maka menurut Yusuf al-Qaradawi harus memenuhi empat syarat sebagai berikut ${ }^{31}$ :

1) Kesimpulan akal yang jelas (sarih al-'aql), mengenai penjelasan kesimpulan akal yang jelas ini, secara tersirat dapat dipahami dari berbagai pernyataan tentang akal dalam karya-karya Yusuf al-Qaradawi, bahwa yang dimaksud adalah kesimpulan akal yang tidak hanya berpegang pada akal secara mutlak akan tetapi harus sejalan dengan ajaran agama. Karena bagaimanapun akal hanyalah sebuah alat untuk memahami ajaran yang terdapat dalam al-Qur'an dan sunnah, bukan untuk menentangnya.

2) Hukum syari'at yang benar (sahih al-syar'i) secara tersirat Yusuf alQaradawi memberikan penjelasan bahwa yang dimaksud disini adalah persoalan agama yang mencakup akidah, ibadah, adab, akhlak, hukum dan mu'amalah. Dengan kata lain syari'at mencakup usul (akidah) dan furu' (mu'amalah).

\footnotetext{
${ }^{30}$ Yusuf al-Qaradawi, Kaifa Nata'amal Ma'a al-Sunnah al-Nabawiyyah, terj. Muhammad al-Baqir,hal. 195

${ }^{31}$ Yusuf al-Qaradawi, Kaifa Nata 'amal al-Sunnah, h. 159
} 
3) Pengetahuan yang pasti (qat'i al-'ilm), secara implisit dalam karyanya al- 'Aqlu wa al- 'Ilm fi al-Qur'an al-Karim, bahwa yang dimaksud dengan pengetahuan yang pasti adalah pengetahuan yang tidak bertentangan dengan iman dan agama yang benar. Jika pengetahuan bertentangan dengan iman dan agama yang benar, makan pengetahuan itu harus diragukana, karena sebetulnya pengetahuan yang benar tidak akan bertentangan dengan sesuatu yang benar pula.

4) Fakta yang tidak diragukan lagi (mu'akkid al-waqi'), sama halnya dengan pengetahuan yang pasti, fakta yang tidak diragukan lagi adalah sesautu yang tidak dikesempingkan dalam mentakwilkan makna yang haqiqi ke makna majazi.

Dilihat dari batasan yang diberikan oleh Yusuf al-Qaradawi dalam mentakwilkan hadis yang mengandung majaz di atas, merupakan upaya agar semaksimal mungkin nilai objektifitas dalam menafsirkan teks dapat diperoleh. Mengingat hadis-hadis yang banyak mengandung majaz sering kali ditakwilkan berdasarkan golongan, aliran maupun subjektifitas sang penafsir. Adapun cakupan hadis yang ditakwilkan oleh Yusuf al-Qaradawi adalah hadis yang berkaitan dengan hadis eskatologi, sifat-sifat Tuhan dan hadis-hadis tentang hokum.

b. Memahami konteks sosio historis ${ }^{32}$

Memahami konteks sosio historis dimaksudkan untuk kajian yang diarahkan pada komplikasi dan rekontruksi sejarah dari data makro bangsa Arab masa Nabi dan kondisi mikro dengan merujuk pada kitab-kitab hadis. Langkah ini diambil Yusuf al-Qaradawi dalam memahami hadis sesuai latar belakang, situasi, kondisi dan tujuan. Asumsi dasar pendekatan sosio historis adalah bahwa Nabi itu didudukkan sebagai fakta sosial yang bersifat historis, bukan sebagai doktrin yang bersifat normative-teologis. Pendekatan sosio historis dalam hal ini adalah suatu upaya memahami hadis dengan cara mempertimbangkan kondisi dan konteks sosio historis pada saat hadis itu disampaikan Nabi saw. ${ }^{33}$

Selanjutnya, pendekatan sosio-historis dimaksudkan untuk mengakses the author Hadis, Yakni Rasulullah saw. melalui titik ini untuk memberi jawaban terhadap pertanyaan “Apa yang dikehendaki Rasulullah secara pasti?". Melalaui pendektan sosio-histori inilah dapat dilacak apa yang dikehendaki oleh Nabi saw. untuk membaca konteks hadis ketika dipahami oleh para generasi awsal yang melihat dan mengamati perilaku Nabi secara dekat. Wilayah utulah yang harus dibidik ketika ingin membaca konteks hadis sebelum kemudian hasil pemahaman tersebut dikontektualisasikan dalam beragam konteks kekinian.

Selain itu, melalui pendekatan sosio historis penafsir Yusuf al-Qaradawi mencoba menemukan ide dasar dengan membedakan antara wilayah tekstual dan kontekstual. Hal ini memungkinkan untuk membedakan antara sarana yang berubah-ubah dengan sarana yang tetap.

\footnotetext{
${ }^{32}$ Pendekatan seperti ini sebenarya telah diperkenalkan oleh para ulama hadis sejak dulu, yaitu dengan munculnya ilmu asbab al-Wurud, yaitu ilmu yang menerangkan sebab-sebab mengapa Nabi saw. menuturkan sabdanya dan waktur menuturkannya. Lihat. M. Hasbi ash-Shiddiqie, Sejarah Ilmu Hadis (Jakarta: Bulan Bintang, 1993), h. 163-164

${ }^{33}$ Abdul Mustaqim, Ilmu Ma'anil Hadis: Paradigma Interkoneksi Berbagai Teori dan Metode Memahami Hadis Nabi (Yogyakarta: Idea Press Yogyakarta, 2016), h. 65.
} 


\section{Analisis Hadis Hukum Memakai Sarung Sampai Di Bawah Mata}

Yusuf al-Qardawi dalam hal ini mencoba mendasarkan pemahamannya dengan mengkorelasikan teks hadis terkait dengan nas al-Qur'an juga teks-teks hadis yang lain (setema dalam arti sealur maupun kontradiktif).

Contoh yang diangkat oleh Yusuf al-Qaradawi untuk memperjelas upaya ini adalah tema tentang Hukum memakai Sarung sampai di bawah mata kaki. Langkah pertama adalah mengemukakan beberapa hadis tentang celaan terhadap hadis orang yang mengenakan sarung sampai bawah mata kaki. Kemudian menyebutkan hadishadis yang berkaitan dengan orang-orang yang mengenakan sarung smapai di bawah mata kaki tanpa dibarengi kesombongan. Selanjutnya ia menampilkan hadis-hadis yang menjelaskan tentang celaan terhadap orang yang menjulurkan sarung atau pakaiannya karena kesombongan.

Disamping itu, Yusuf al-Qaradawi juga mengungkapkan penjelasanpenjelasan dari beberapa ulama, di antarannya Ibn hajar (w.852) dan al-Nawawi (w.676). dan menyimpulkan dengan mengumpulkan hadis yang dalalahnya muthlaq pada hadis-hadis yang dalalahnya muqayyad, bahwa ancaman terhadap perbuatan menjulurkan sarung itu terbatas kepada orang-orang yang melakukannya karena kesombongan dan kebanggan diri saja. Jika menjulurkan sarung itu terbatas kepada orang yang melakukannya karena adat kebiasaan maka tidak termasuk ancaman.

Dari sini, Yusuf al-Qaradawi mencoba menarik pemaknaan kontekstualisasi dari sebuah hadis dengan memberi argument bahwa substansi yang ingin dicapai dari hadis tentang menjulurkan pakaiana ini terfokus pada niat berpakaian dan tidak berlebihan. Sedangkan bentuk dan lainnya sangat tergantung dengan kebiasaan dan tradisi.

\section{KESIMPULAN}

Metode pendekatan yang digagas oleh Yusuf al-Qaradawi adalah upaya melahirkan teori baru sebagai alternatif dalam memahami hadis yang lebih orisinil dan komprehensif tanpa harus benar-benar meninggalkan teori-teori klasik yang dianggapnya masih relevan secara metodologis dengan realitas masyarakat saat ini.

Pemikiran Yusuf al-Qaradawi sebagai bentuk pengembangan terhadap teoriteori klasik agar dalam kajian hadis kedepannya tidak mesti harus terlepas dari akar teologisnya namun tetap tidak mengambaikan kondisi sosiologis masyarakat. Melalui metode ini juga diharapkan para pembaca mampu memperoleh pemahaman hadis yang lebih tepat, apresiasif, dan akomodatif dalam melihat realitas masyarakat yang dinamis dan berubah-ubah.

Setalah melalui pembahasan yang telah terdapat dalam beberapa sub bab yang telah dijelaskan di atas, dapat ditarik pemahaman bahwa metode pemahaman hadis Yusuf al-Qaradawi adalah hadis-hadis yang mencakup problem-problem seputar kebudayaan. Respon ini dibarengi dengan sikapnya mengambil posisi "tengah-tengah".

Selebihnya produk pemikiran Yusuf al-Qaradawi masih menyadur metode pemahaman hadis yang masih memiliki atau terkait dengan pemikiran yang berkembang sebelumnya. Namun, kontribusi penting dari Yusuf al-Qaradawi 
terletak pada aplikasi teori ke dalam masalah yang bersiggungan dengan persoalan kontemporer.

\section{Daftar Pustaka}

Abdul Mustaqim, Ilmu Ma'anil Hadis: Paradigma Interkoneksi Berbagai Teori dan Metode Memahami Hadis Nabi . Yogyakarta: Idea Press Yogyakarta, 2016.

Kurdi dkk, Hermeneutika al-Qur'an dan Hadis. Cet. I; Yogyakarta: eLSAQ Press, 2010.

Jamal al-Banna, Nahw Fiqh Jadid;al-Sunnah wa Dauruha fi al-Fiqh al-Jadid. Kairo: Dar al-Fikr al-Islami, 1997

M. Hasbi ash-Shiddiqie, Sejarah Ilmu Hadis. Jakarta: Bulan Bintang, 1993.

Sahiron Syamsuddin, Hermeneutika dan Pengembangan Ulumu Qur'an. Yogyakarta: Pesantren Nawesea Press, 2009.

Suryadi, Metode Kontemporer Memahami Hadis Nabi, Cet. I. Yogyakarta: Teras, 2008.

Sutopo, Analisis Hermeneutik atas Pemikiran Yusuf Qardhawi tentang HadisHadis Ekonomi, Iqtishadia, Vol. 8, No. 2, September 2015.

Ahmad, Arifuddin, Metodologi Pemahaman Hadis: Kajian Ilmu Ma'ani al-Hadis. Makassar: Alauddin University Press, 2013.

Al-Qardhawi, Yusuf, Min Fiqh al-Daulah fi al-Islam, Makanatuha, Ma'alimuha, Thabi'atuha, Mauqifuha, min al Dimaqratiyah wa al-Ta'addudiyah wa alMaar'ah wa Ghairu al-Muslimin. Cairo: Dar al-Syuruq, 1997.

Al-Qaradawi,Yusuf, Kaifa Nata'amal Ma'a al-Sunnah al-Nabawiyyah, terj. Muhammad al-Baqir.Cet. IV; Bandung: Kaarisma, 1995.

'Isa al-Thurmudziy, Abu 'Isa Muhammad, al-Jami' al-Kabir (Beirut: Dar al'Arabiy al-Islamiy, 1998. 